\title{
Lannoitustavan vaikutus perunan ravinteiden saantiin ja mukuloiden kemialliseen koostumukseen
}

EERO VARIS

Hankkijan kasvinjalostuslaitos, Anttilan koetila, 04300 Hyrylä

\section{The effects of the fertilizer application method on the nutrient uptake of the potato and the chemical composition of the tubers}

\author{
Plant Breeding Institute of Hankkija, Experimental Farm Anttila, Hyrylä, Finland
}

\begin{abstract}
The effects of fertilizer drilling and placement upon uptake of nutrients by the potato were compared with the effects of broadcasting at the Plant Breeding Institute of Hankkija, Anttila Experimental Farm from 1968-71. Rates of 650 and $1300 \mathrm{~kg}$ of chloride free complete fertilizer per hectare were used in the experiments. There were four lifting times, and the variety was Record.

The uptakes of nitrogen and potassium increased steadily, whereas those of phosphorus and particularly of magnesium and calcium showed irregular variations during the growing season.

Increase in the fertilizer rate altered the composition of potato turbers during the autumn as follows: dry matter $21.8-21.8$, N 1.14-1.27, P $14.1-13.7$, K 2.24-2.26, $\mathrm{Ca} 0.038-0.040$ and $\mathrm{Mg} 0.145-0.140$. The method of fertilizer application affected the contents as follows: (broadcasting - drilling - placement) DM $21.4-22.2$ - 21.7, $\mathrm{N} 1.30-1.33-1.32$, P $0.186-0.171-0.189$, K $2.30-2.21-2.24$, Ca $0.042-0.040-$ 0.035 and $\mathrm{Mg} 0.144-0.142-0.142$.
\end{abstract}

Lannoitteiden multaaminen tai sijoittaminen on osoittautunut Suomen olosuhteissa tehokkaaksi satoa lisääväksi toimenpiteeksi. Kevätviljoilla on voitu osoittaa, että sadon lisäyksien parhaita selittäjiä on parantunut ravinteiden saanti alkukesästä (AUra 1967, Nieminen ym. 1967, Pessi ym. 1970). Myös perunan sijoituslannoituskokeet Suomessa ovat osoittaneet selviä sadonlisäyksiä (LARPES 1968, VARIS ja LANNETTA 1974). Selostettavassa tutkimuksessa pyrittiin selvittämään, missä määrin todetut sadonlisäykset noudattivat ravinteiden saannin mahdollisia muutoksia ja missä määrin lannoitustapa vaikutti mukuloiden kemialliseen koostumukseen.

\section{Aineisto ja käsittely}

Koeaineisto käsitti vuosina 1968 -71 perustetut lannoitustapakokeet, joista tehtiin kasvututkimus neljänä nostoaikana. Kokeiden järjestely on tarkemmin 
selvitetty aikaisemmin (VARIS ja LAnnetTa 1974). Nostojen yhteydessä otetuista lehdistö- ja mukulanäytteistä analysoitiin Satoturve Oy:ssä N-, P-, K-, Ca- ja Mg-pitoisuudet. Tulosten käsittelyssä käytettiin varianssianalyysejä ja regressioanalyysejä, jotka laskettiin Keskusosuusliike Hankkijan ATK-osastolla. Tulosten tilastollinen merkitsevyys on ilmaistu tavalliseen tapaan.

\section{Kuiva-aine}

Varianssianalyysien tulokset kuiva-aineen määrästä $\mathrm{kg} / \mathrm{ha}$ ja kuiva-ainepitoisuuksista ilmenevät Taulukosta 1 .

Taulukko 1. Varianssianalyysi lannoitustavan vaikutuksesta perunan ravinteiden saantiin ja mukuloiden kemialliseen koostumukseen.

Table 1. Analysis of variance of the effects of the fertilizer application method on the nutrient uptake of potatoes and the chemical composition of the tubers.

\begin{tabular}{|c|c|c|c|c|c|c|c|c|c|c|c|c|}
\hline \multirow[t]{2}{*}{$\begin{array}{l}\text { Tekijä } \\
\text { Factor }\end{array}$} & \multicolumn{12}{|c|}{ Kuiva-aine } \\
\hline & $\mathrm{kg} / \mathrm{ha}$ & $\%$ & $\begin{array}{c}\mathrm{N} \\
\mathrm{kg} / \mathrm{ha}\end{array}$ & $\%$ & $\begin{array}{c}\mathrm{P} \\
\mathrm{kg} / \mathrm{ha}\end{array}$ & $\%$ & $\begin{array}{c}\mathrm{K} \\
\mathrm{kg} / \mathrm{ha}\end{array}$ & $\%$ & $\begin{array}{c}\mathrm{Ca} \\
\mathrm{kg} / \mathrm{ha}\end{array}$ & $\%$ & $\begin{array}{c}\mathrm{Mg} \\
\mathrm{kg} / \mathrm{ha}\end{array}$ & $\%$ \\
\hline A. Vuosi - Year .......... & $* * *$ & $* * *$ & $* * *$ & $* * *$ & $* * *$ & $* * *$ & $* * *$ & $* * *$ & $* * *$ & *** & $* * *$ & *** \\
\hline $\begin{array}{l}\text { B. Varsisto/mukulat ....... } \\
\text { Haulms/tubers }\end{array}$ & $* * *$ & $* * *$ & ns & $* * *$ & $* * *$ & *** & $* * *$ & $* * *$ & $* * *$ & $* * *$ & $* * *$ & $* * *$ \\
\hline $\begin{array}{l}\text { C. Nostoaika } \\
\text { Harvest time }\end{array}$ & $* * *$ & $* * *$ & $* * *$ & $* * *$ & $* * *$ & $* * *$ & $* * *$ & $* * *$ & $* * *$ & $* * *$ & $* * *$ & $* * *$ \\
\hline $\begin{array}{l}\text { D. Lannoitemäärä .......... } \\
\text { Fertilizer rate }\end{array}$ & ns & $* * *$ & $* * *$ & $* * *$ & $*$ & ns & $*$ & ns & $*$ & ns & ns & ns \\
\hline $\begin{array}{l}\text { E. Lannoitustapa ........... } \\
\text { Application method }\end{array}$ & $* * *$ & ns & $* * *$ & ns & $(*)$ & * & $* * *$ & ns & ns & $(*)$ & $(*)$ & ns \\
\hline 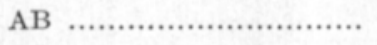 & $* * *$ & $* * *$ & $* * *$ & $* * *$ & $* * *$ & $* * *$ & $* * *$ & $* * *$ & $* * *$ & $* * *$ & $* * *$ & $* * *$ \\
\hline AC ...... & $* * *$ & $* * *$ & $*$ & $* * *$ & $* * *$ & $* * *$ & $* * *$ & $* * *$ & $* * *$ & $* * *$ & $* * *$ & $* * *$ \\
\hline 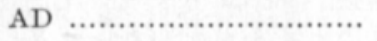 & $* *$ & ns & ns & $(*)$ & ns & $* * *$ & $* * *$ & $(*)$ & ns & ns & ns & ** \\
\hline 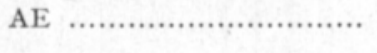 & ns & ** & $* *$ & ns & ns & $* * *$ & ns & ns & ns & $* *$ & ns & ns \\
\hline BC $\ldots .$. & $* * *$ & $* * *$ & $* * *$ & $* * *$ & $* * *$ & $* * *$ & $* * *$ & $* * *$ & $* * *$ & $* *$ & $* * *$ & $* * *$ \\
\hline BD $\ldots \ldots \ldots . .$. & ns & $* * *$ & ns & $(*)$ & ns & $(*)$ & $*$ & ns & $(*)$ & ns & $(*)$ & ns \\
\hline 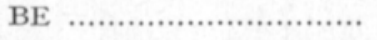 & ns & ns & $*$ & ns & ns & ns & ns & ns & ns & $(*)$ & ns & ns \\
\hline 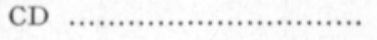 & ns & ns & ns & ns & ns & ns & $*$ & ns & ns & ns & $* *$ & ns \\
\hline 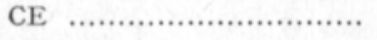 & $(*)$ & $*$ & $* *$ & ns & ns & ns & ns & ns & ns & ns & $*$ & * \\
\hline 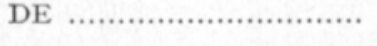 & ** & ns & $* * *$ & ns & $*$ & * & $* * *$ & ns & ns & ns & * & $(*)$ \\
\hline $\mathrm{ABC} \ldots$ & $* * *$ & $* * *$ & $* * *$ & $* * *$ & $* * *$ & $* * *$ & $* * *$ & $* * *$ & $* * *$ & $* * *$ & $* * *$ & $* * *$ \\
\hline ABD ... & $* * *$ & $* *$ & ns & ns & $*$ & ns & $* * *$ & ns & ns & ns & $* * *$ & ** \\
\hline 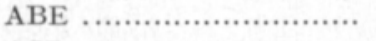 & ns & ns & ns & ns & ns & $(*)$ & ns & ns & ns & $* *$ & $(*)$ & ns \\
\hline 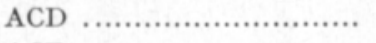 & $* *$ & ns & $*$ & ns & ns & ns & $* *$ & ns & $*$ & ns & $* *$ & ns \\
\hline ACE... & ns & ns & $* * *$ & ns & $(*)$ & ns & ** & ${ }^{*}$ & ns & $* *$ & $*$ & ns \\
\hline 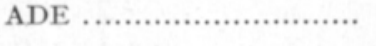 & ns & $*$ & ns & ns & $(*)$ & ns & $* *$ & ns & ns & ns & $(*)$ & ns \\
\hline BCD .... & ns & ns & $* *$ & $*$ & ns & ns & ns & ns & ns & ns & ns & ns \\
\hline BCE .... & ns & ns & ns & ns & ns & $(*)$ & ns & ns & ns & ns & $(*)$ & * \\
\hline 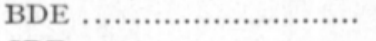 & ns & ns & $*$ & ns & ns & ns & $(*)$ & ns & ns & ns & ns & $*$ \\
\hline 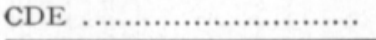 & $*$ & ns & $*$ & ns & ns & ns & $* *$ & ns & ns & ns & ns & ns \\
\hline
\end{tabular}


Lannoituksen määrä ei vaikuttanut merkitsevästi perunan kokonaiskuivaainesatoon syksyllä (8731 ja $8582 \mathrm{~kg} / \mathrm{ha}$ ), joskin vuotuista vaihtelua oli (AD). Keskimääräinen kuiva-ainepitoisuus aleni lievästi (16.3 ja $15.9 \%$ ), mikä johtui tosin vain lehdistön kuiva-ainepitoisuuden alenemisesta ( $\mathrm{BD}, 11.8$ ja 11.2). Kuiva-aineen muodostuksen rytmissä ei ollut keskimäärin selvää eroa (CD, $\mathrm{BCD})$.

Lannoitustapa sen sijaan vaikutti selvästi lopulliseen kokonaiskuiva-ainesatoon (Piirros 1, 8410, 9137 ja 8422 kg/ha). Keskimääräisissä kuiva-ainepitoisuuksissa ei sen sijaan ollut eroja.

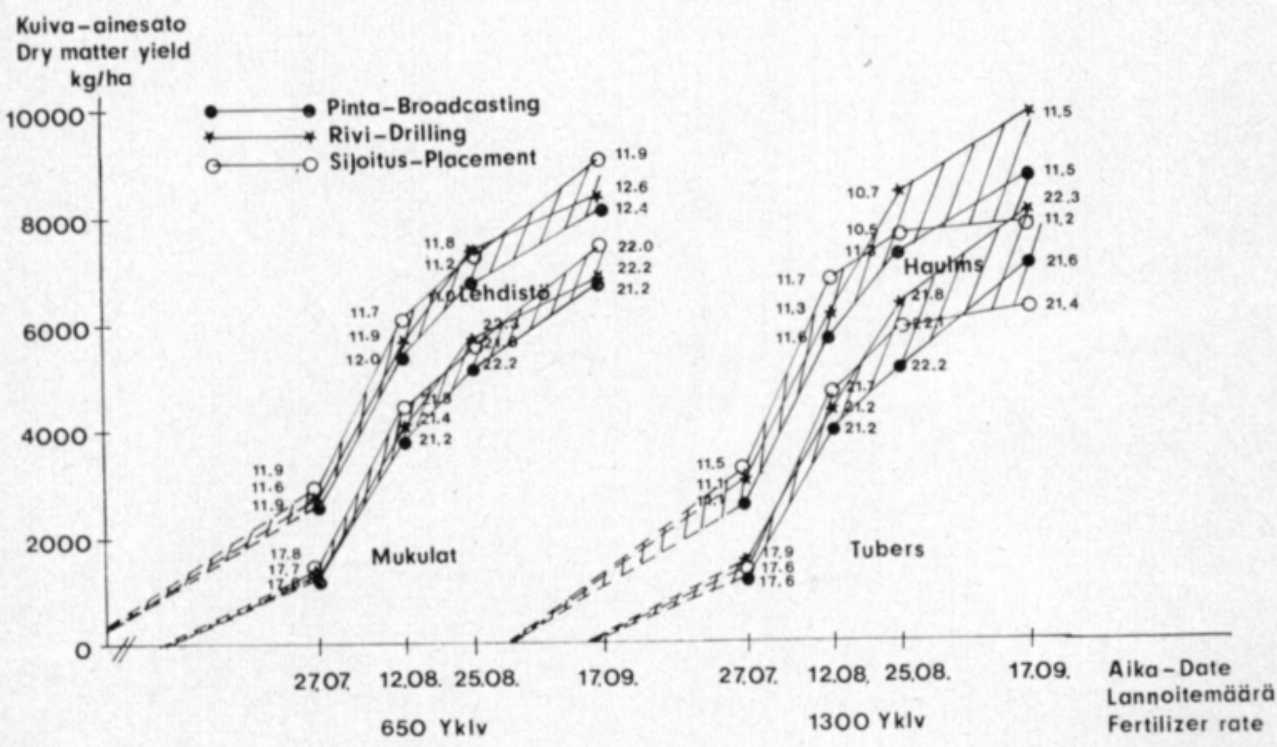

Piirros 1. Lannoitustavan vaikutus perunan kuiva-ainesadon kehittymiseen kahta lannoitemäärää käytettäessä.

Figure 1. Effect of fertilizer application method on the development of the dry matter yield of the potato at two fertilizer rates.

Pientä lannoitemäärää käytettäessä sijoituslannoitus oli edullisin lannoitustapa kuiva-aineen muodostumisen kannalta $(8122,8438$ ja $9056 \mathrm{~kg} / \mathrm{ha})$, kun taas isoa lannoitemäärää käytettäessä rivilannoitus tuotti suurimman kuiva-ainesadon (8698, 9838 ja $7788 \mathrm{~kg} / \mathrm{ha})$.

Kuiva-aineen muodostuminen oli sijoituslannoitusta käytettäessä alkukesästä nopeinta, mutta hidastui syksyllä isoa lannoitemäärää käytettäessä (CE, CDE). Rivilannoituksessa taas kuiva-ainetta muodostui varsinkin isoa lannoitemäärää käytettäessä kasvukauden loppupuolella runsaasti. Mukuloiden kuiva-ainepitoisuus aleni syksyllä pintalannoitusta käytettäessä (17.6$21.1-22.2-21.4 \%$ ), kun se taas rivilannoituksessa pysyi korkeana (17.8$21.4-22.0-22.2 \%$ ). Sijoituslannoituksessa kuiva-ainepitoisuus pysyi samalla tasolla koko kasvukauden loppupuolen, mutta jäi alemmaksi kuin rivilannoituksessa $(17.7-21.7-21.8-21.7 \%)$. 


\section{Typpi}

Lannoituksen määrän kaksinkertaistaminen lisäsi perunan sisältämää typpimäärää syksyllä (Piirros 2, 128 ja $141 \mathrm{~kg} / \mathrm{ha}$ ). Tämä johtui kuitenkin vain $\mathrm{N}$-pitoisuuden noususta, koska kuiva-aineen määrä ei lisääntynyt merkitsevästi. N-pitoisuuden keskimääräinen nousu oli suurempi lehdistössä (3.30 ja $3.50 \%$ ) kuin mukuloissa (1.14 ja $1.27 \%$ ), joskin prosentuaalisesti suurempi mukuloissa (BD). Kasvien typpimäärän ja N-pitoisuuden nousu oli keskimäärin havaittavissa koko kasvukauden ajan (CD), mutta se kohdistui alkukesästä vain lehdistöön, loppu乏̌esästä myös mukuloihin (BCD).

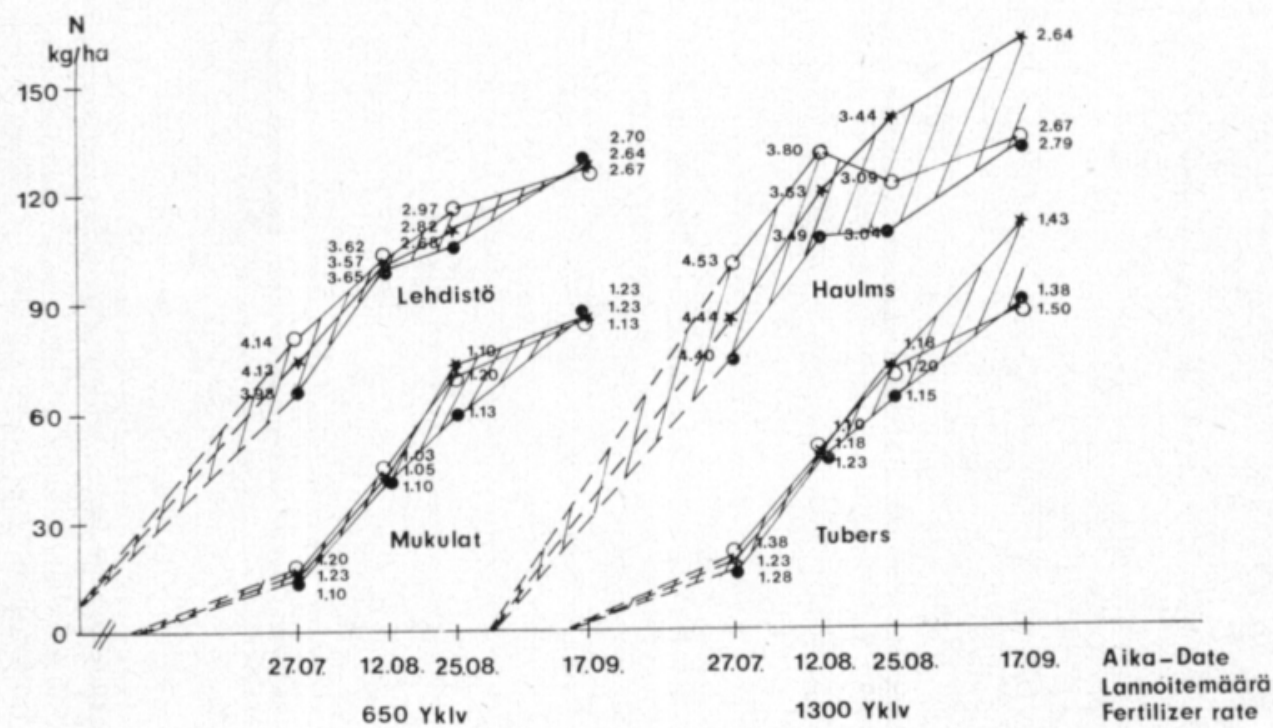

Piirros 2. Lannoitustavan vaikutus perunan typen saantiin kahta lannoitemäärää käytettäessä. Figure 2. Effect of fertilizer application method on the nitrogen uptake of the potato at two fertilizer rates.

Myös lannoitustapa vaikutti kasvien kokonaistyppimääriin syksyllä (130, 144 ja $130 \mathrm{~kg} / \mathrm{ha})$. Kokonaistyppimäärän lisäys oli kuitenkin riippuvainen lannoitemäärästä. Alhaisella lannoitustasolla vain sijoituslannoitus lisäsi ajoittain kasvuston typpimäärää, suurempaa lannoitemäärää käytettäessä varsinkin rivilannoituksessa kasvuston typpimäärä oli syksyllä suuri. Typpimäärän lisäys kohdistui rivilannoituksessa sekä lehdistöön että mukuloihin, sijoituslannoituksessa keskimäärin enemmän lehdistöön (BE). Tämä ilmiö oli selvä kuitenkin vain isompaa lannoitemäärää käytettäessä (BDE). Sijoituslannoituksessa perunan saama typpimäärä nousi voimakkaasti jo alkukesästä, mutta pysähtyi sen jälkeen. Rivilannoitusta käytettäessä perunan typpimäärä nousi koko kesän ja syksyllä selvästi suuremmaksi kuin muilla lannoitustavoilla (CE). Tämä ero tuli esille isompaa lannoitemäärää käytettäessä (CDE, syksyllä pieni lannoitemäärä 133,125 ja $125 \mathrm{~kg} / \mathrm{ha}$, iso lannoitemäärä $128,162$ ja $135 \mathrm{~kg} / \mathrm{ha})$. 
Lannoitustapa ei keskimäärin vaikuttanut mukuloiden N-pitoisuuksiin syksyllä. Sen sijaan lannoitemäärän lisääminen nosti kaikissa lannoitustavoissa mukuloiden N-pitoisuutta syksyllä: pintalannoitus 1.23 ja $1.38 \%$, rivilannoitus 1.23 ja $1.43 \%$ sekä sijoituslannoitus 1.13 ja $1.50 \%$.

\section{Fosfori}

Lannoituksen lisääminen nosti kasvukauden aikana keskimäärin lievästi perunan fosforin ottoa (Piirros 3, D), vaikka syksyllä eroa ei ollutkaan (14.1 ja $13.7 \mathrm{~kg} / \mathrm{ha}$ ). Lehdistön P-pitoisuus nousi lievästi (BD, lehdistö 0.161 ja $0.168 \%$, mukulat 0.176 ja $0.175 \%$ ). Kasvukauden aikana tilanne oli koko ajan samanlainen (CD). Syksyllä mukuloiden fosforipitoisuudet olivat kummallakin lannoitemäärällä samat $(0,179 \%)$.

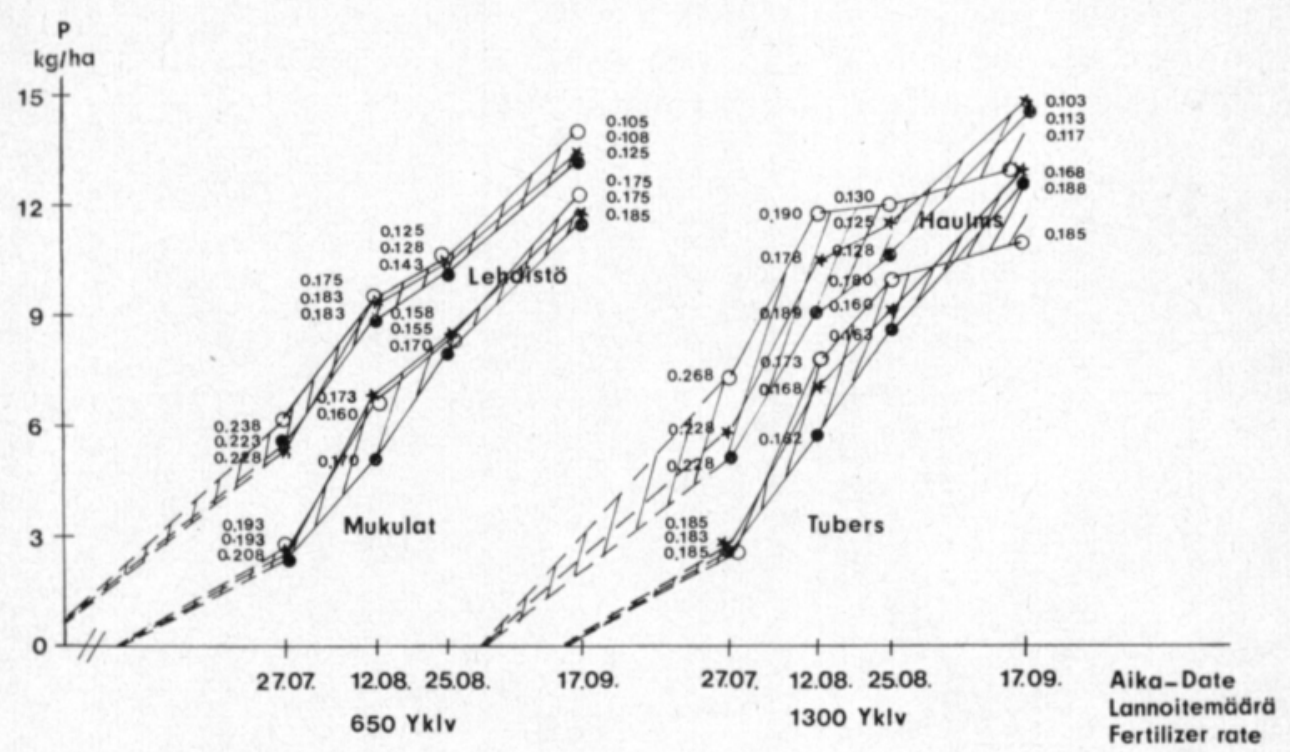

Piirros 3. Lannoitustavan vaikutus perunan fosforin saantiin kahta lannoitemääräă käytettäessä• Figure 3. Effect of fertilizer application method on the phosphorus uptake of the potato at two fertiluzer rates.

Lannoitustapa vaikutti sekä perunan fosforimäärään syksyllä (13.9, 14.2 ja $13.5 \mathrm{~kg} / \mathrm{ha})$ että keskimääräiseen P-pitoisuuteen $(0.173,0.166$ ja $0.172 \%)$. Mukuloiden P-pitoisuudet syksyllä olivat $0.186,0.171$ ja $0.189 \%$ ). Lehdistön ja mukuloiden P-pitoisuudet muttuivat kasvukauden kuluessa eri tavalla riippuen lannoitustavasta (BCE). Pintalannoituksessa lehtien P-pitoisuus oli alussa matala, mutta nousi sen jälkeen muita lannoitustapoja ylemmäksi ja jäi myös syksyllä korkeaksi. Mukuloiden P-pitoisuus oli taas alussa korkea ja sen jälkeen keskinkertainen. Rivilannoituksessa lehtien P-pitoisuus oli koko kasvukauden ajan matala, mukuloiden alussa keskinkertainen, syyskesällä matala. Sijoituslannoituksessa lehdistön P-pitoisuus oli kasvukauden alussa hyvin korkea, mutta loppukesällä matalahko. Mukuloiden P-pitoisuus oli alussa matalahko, myöhemmin keskinkertainen. 
Lannoitemäärällä ja lannoitustavalla oli yhdysvaikutus sekä P-pitoisuuteen että fosforimäärään nähden. Sijoituslannoituksen isoa lannoitemäärää käytettäessä perunan P-pitoisuus nousi huomattavasti, kun se pintalannoituksessa pysyi muuttumattomana ja rivilannoituksessa lievästi laski. Fosforimäärä nousi sekä rivi- että sijoituslannoituksessa selvästi, kun se pintalannoituksessa pysyi lähes muuttumattomana. Syksyllä sijoituslannoituksen fosforimäärä jäi kuitenkin isoa lannoitemäärää käytettäessä alhaiseksi, mikä ero ei kuitenkaan ollut tilastollisesti merkitsevä samalla tavalla kuin kuiva-ainesadon ja typpisadon osalta.

\section{Kalium}

Lannoituksen lisääminen nosti hiukan perunan ottamaa kaliumin määrää kasvukauden aikana, joskin syksyllä ero oli tasaantunut (Piirros 4, syksyllä 232 ja $237 \mathrm{~kg} / \mathrm{ha})$. Kaliumin määrä lisääntyi pääasiassa lehdistössä (BC). Mukuloiden K-pitoisuudet syksyllä olivat 2.24 ja 2.26 .

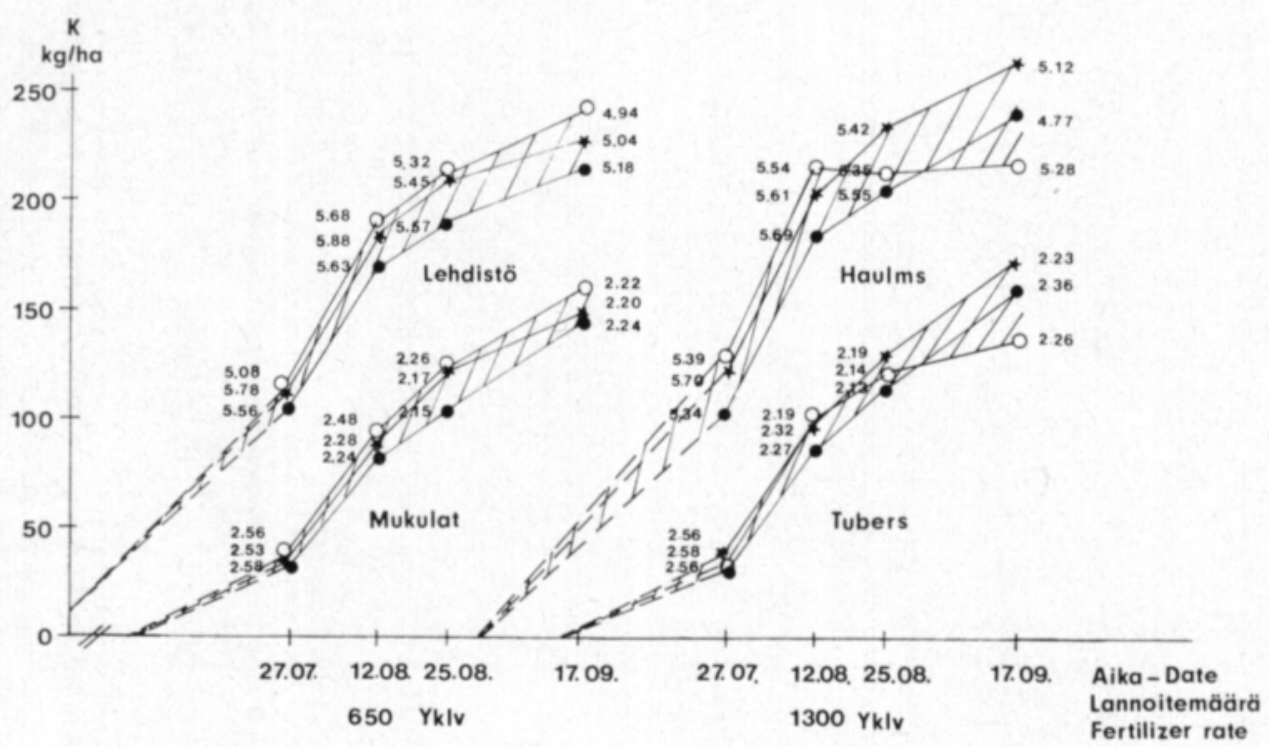

Piirros 4. Lannoitustavan vaikutus perunan kaliumin saantiin kahta lannoitemäärää käytettäessä.

Figure 4. Effect of fertilizer application method on the potassium uptake of the potato at two fertilizer rates.

Lannoitustapa vaikutti perunan ottamiin kaliumin määriin kuiva-ainesadon muutosten suhteessa (E), sillä K-pitoisuuksissa ei ollut merkitseviä eroja. Pintalannoituksessa kaliumin määrä oli syksyllä $228 \mathrm{~kg} / \mathrm{ha}$, rivilannoituksessa $246 \mathrm{~kg} / \mathrm{ha}$ ja sijoituslannoituksessa $230 \mathrm{~kg} / \mathrm{ha}$. Lehdistön ja mukuloiden kaliuminotto erosi samalla tavalla (BE). Samoin koko kasvukauden aikana erot olivat samansuuntaiset (CE). Syksyllä mukuloiden K-pitoisuudet olivat $2.30,2.21$ ja $2.24 \%$, mitkä erot eivät kuitenkaan olleet merkitseviä. 
Lannoituksen määrällä ja tavalla oli kaliumin määrien suhteen yhdysvaikutus (DE), joka noudatti kuiva-ainesatojen muutoksia.

\section{Kalsium}

Lannoituksen määrän lisääminen nosti perunan saamaa kalsiummäärää lievästi (D). Ca-pitoisuus ei muuttunut keskimäärin merkitsevästi, joskin suunta oli nouseva. Kalsiummäärä lisääntyi vain lehdistössä (BD). Syksyllä kokonaiskalsiummäärät olivat 27 ja $28 \mathrm{~kg} /$ ha. Mukuloiden Ca-pitoisuuksissa syksyllä ei ollut merkitseviä eroja $(0.038$ ja $0.040 \%)$.

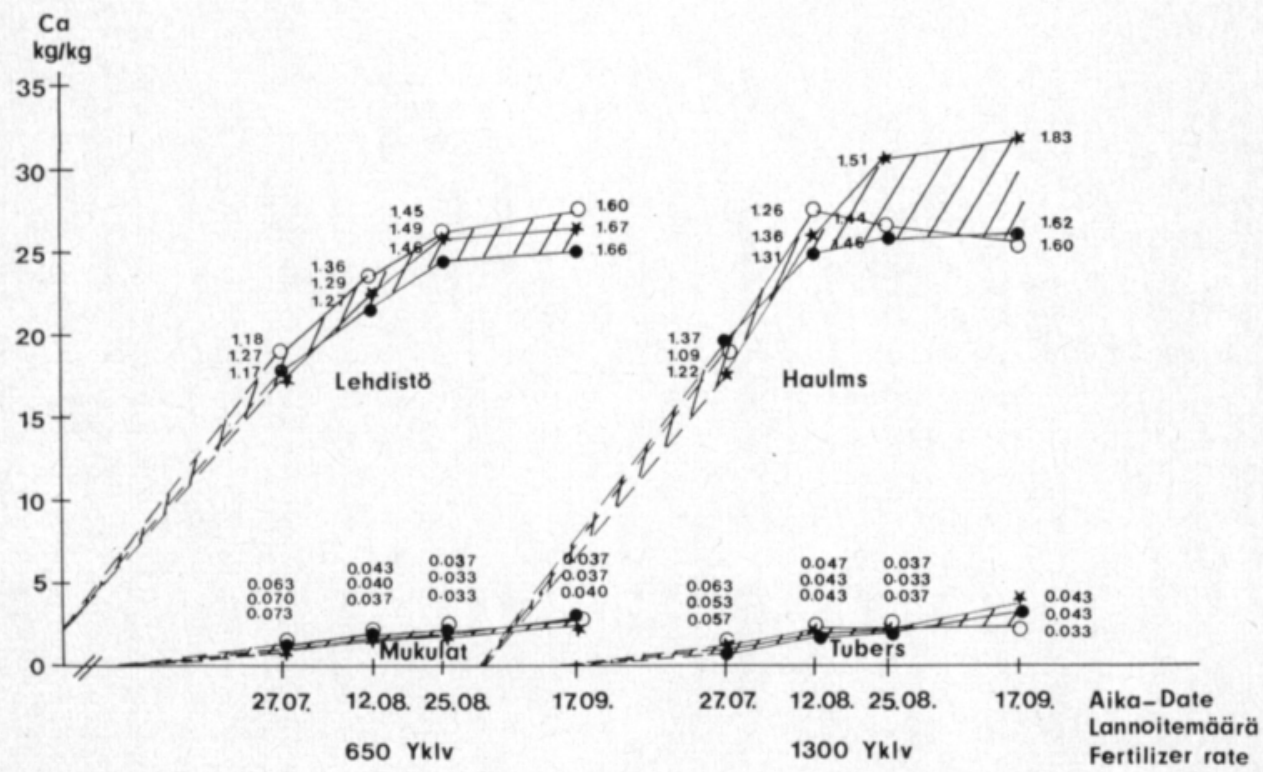

Piirros 5. Lannoitustavan vaikutus perunan kalsiumin saantiin kahta lannoitemäärää käytettäessä.

Figure 5. Effect of fertilizer application method on the calcium uptake of the potato at two fertilizer rates.

Lannoitustapa ei lisännyt merkitsevästi perunan kalsiumin käyttöä, joskin suunta oli sama kuin kuiva-ainesadoissa (Piirros 5). Lehdistön Ca-pitoisuuksissa oli lieviä eroja (E, BE, pintalannoitus 1.43, rivilannoitus 1.44 ja sijoituslannoitus $1.37 \%$ ). Kokonaiskalsiumpitoisuudet olivat 13,15 ja 13 $\mathrm{kg} / \mathrm{ha}$, mukuloiden Ca-pitoisuudet syksyllä $0.042,0.040$ ja $0.035 \%$. Sijoituslannoituksessa perunan kalsiumin käyttö näytti siis olevan suhteellisen niukkaa.

\section{Magnesium}

Lannoituksen lisääminen muutti hiukan perunan magnesiumin käyttöä (Piirros 6). Lehdistön magnesiumin määrä lisääntyi jossain määrin (BD), joskin koko kasvin käyttämissä magnesiummäärissä ei ollut eroa (D). Mag- 
nesiumin saanti lisääntyi toisessa ja neljännessä nostossa (CD). Magnesiumin kokonaismäärät olivat syksyllä 19 ja $21 \mathrm{~kg} / \mathrm{ha}$. Mukuloiden Mg-pitoisuudet olivat 0.145 ja $0.140 \%$.

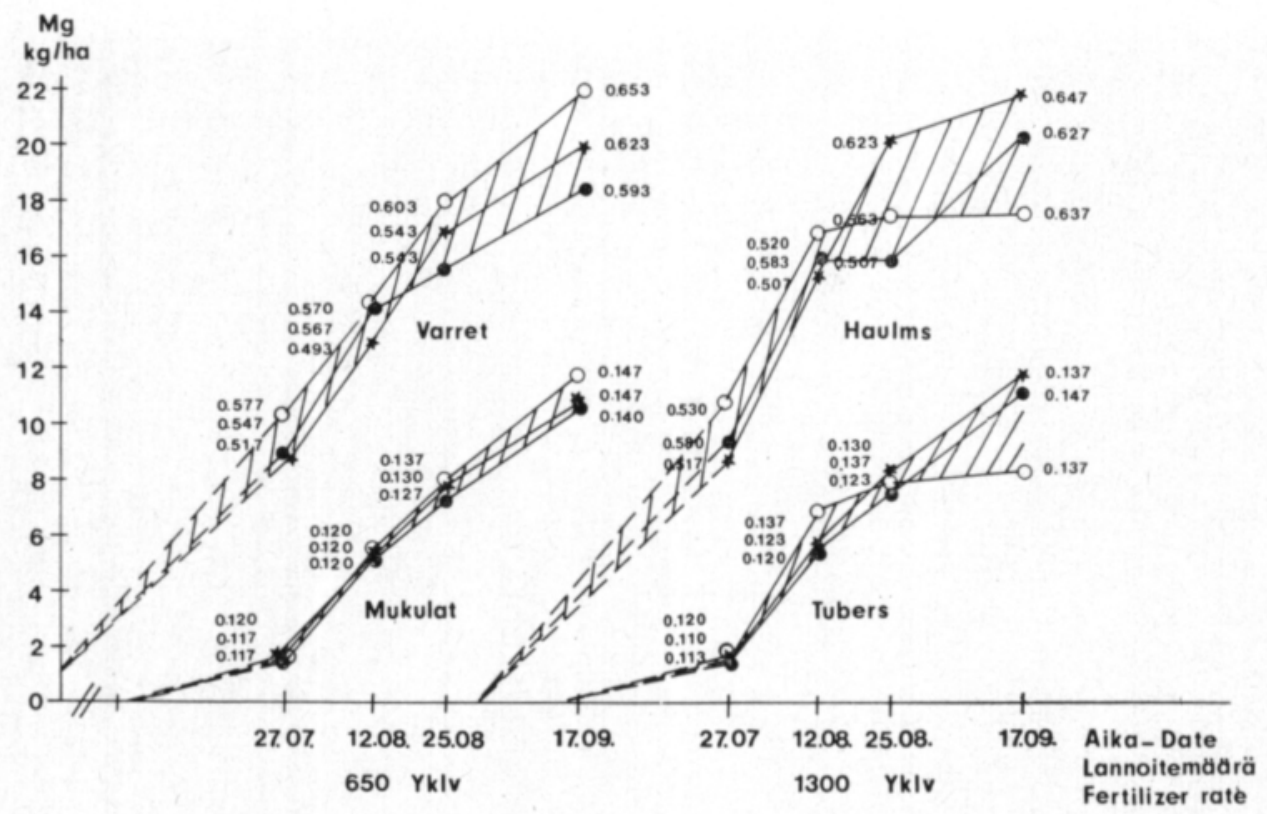

Piirros 6. Lannoitustavan vaikutus perunan magnesiumin saantiin kahta lannoitemäärää käytettäessä.

Figure 6. Effect of fertilizer application method on the magnesium uptake of the potato at two. fertilizer rates.

Lannoitustapa vaikutti selvemmin perunan magnesiumin käyttöön. Magnesiumin saanti oli sijoituslannoituksessa alkukesästä selvästi runsaampaa kuin muissa lannoitustavoissa (CE). Loppukesällä taas rivilannoituksessa magnesiumin määrä oli suurin varsinkin isompaa lannoitemäärää käytettäessä. Syksyllä kokonaismagnesiummäärät olivat 19,21 ja $20 \mathrm{~kg} / \mathrm{ha}$, mukuloiden Mg-pitoisuudet $0.144,0.142$ ja $0.142 \%$.

Yhdysvaikutus DE oli myös merkitsevä osoittaen, miten pienempää lannoitemäärää käytettäessä sijoituslannoituksessa varsinkin lehdistön magnesiumin saanti oli muita lannoitustapoja runsaampaa. Samalla myös kasvien, varsinkin lehtien Mg-pitoisuus nousi (BDE). Isompaa lannoitemäärää käytettäessä taas rivilannoituksessa lehdistön magnesiumin saanti oli parasta varsinkin loppukesällä (BCE).

\section{Ravinteiden saanti ja kuiva-ainesadon kehitys}

Edellä esitettyjen tulosten perusteella haluttiin lähemmin selvittää perunan kuiva-ainesadon kehityksen ja ravinteiden käytön välisiä suhteita. Tarkoitusta varten laskettiin korrelaatiot kokonaiskuiva-ainesatojen ja käytettyjen ravinnemäärien välille (Taulukko 2). 
Taulukko 2. Perunan kuiva-ainesadon ja ravinteiden oton välinen riippuvuus. Table 2. Correlation between nutrient uptake and dry matter yield of potatoes.

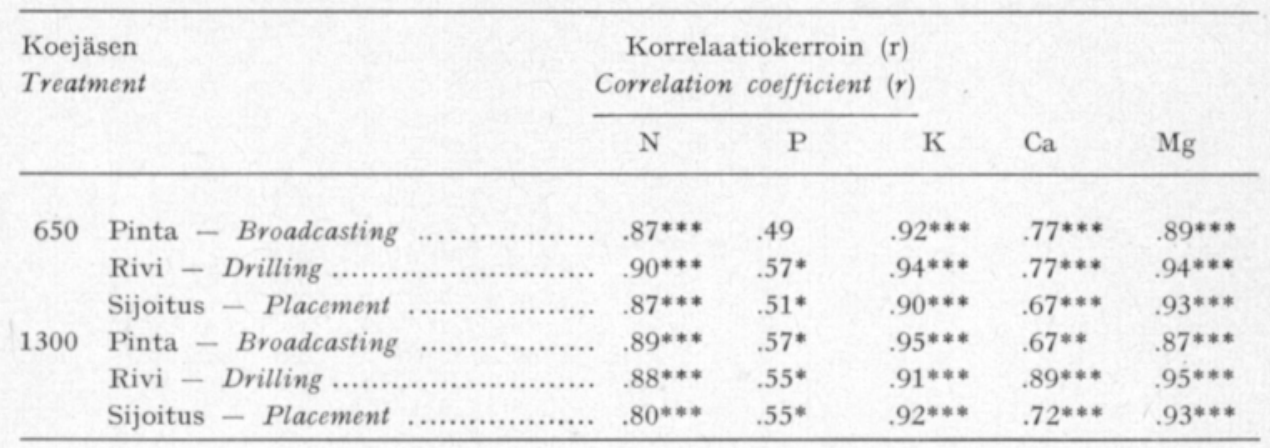

Ravinteiden määrän ja kuiva-ainesadon välinen riippuvuus oli kiintein kaliumin, magnesiumin ja typen osalta. Kalsiumin suhteen oli suurta vaihtelua, kun taas fosforin ja kuiva-ainesadon väliset korrelaatiot olivat kauttaaltaan muita löysemmät.

Korrelaatiokerrointen tulkinnan helpottamiseksi laskettiin vielä kuiva-ainesadon ja ravinteiden käytön suhteelliset lisäykset koejäseneen Pinta-650 verrattuna.

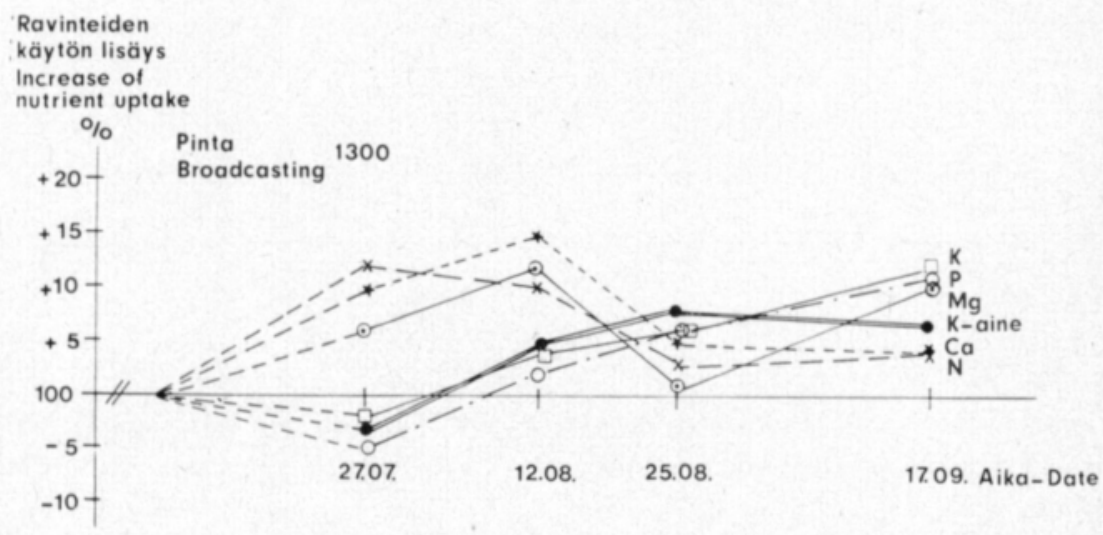

Piirros 7. Kuiva-ainesadon ja ravinnemäärien lisäys pintalannoituksessa lannoitemäärän kaksinkertaistuessa (Pinta-650 $=100$ ).

Figure 7. The increases of dry matter yield and nutrient uptakes using broadcasting at the doubled fertilizer rate (Broadcasting $650=100$ ).

Koejäsenen Pinta-1300 tapauksessa (Piirros 7) typen, kalsiumin ja magnesiumin saanti lisääntyi kasvukauden alkupuolella selvästi. Kasvukauden loppupuolella näiden ravinteiden saanti kuitenkin hidastui joko tilapäisesti '(magnesium) tai pysyvästi (typpi ja kalsium), ja samalla kuiva-aineen lisäys tasaantui. Kaliumia ja fosforia peruna otti alkukesästä niukanlaisesti, syksyllä suhteellisen runsaasti (vrt. VARIS 1973 b). 

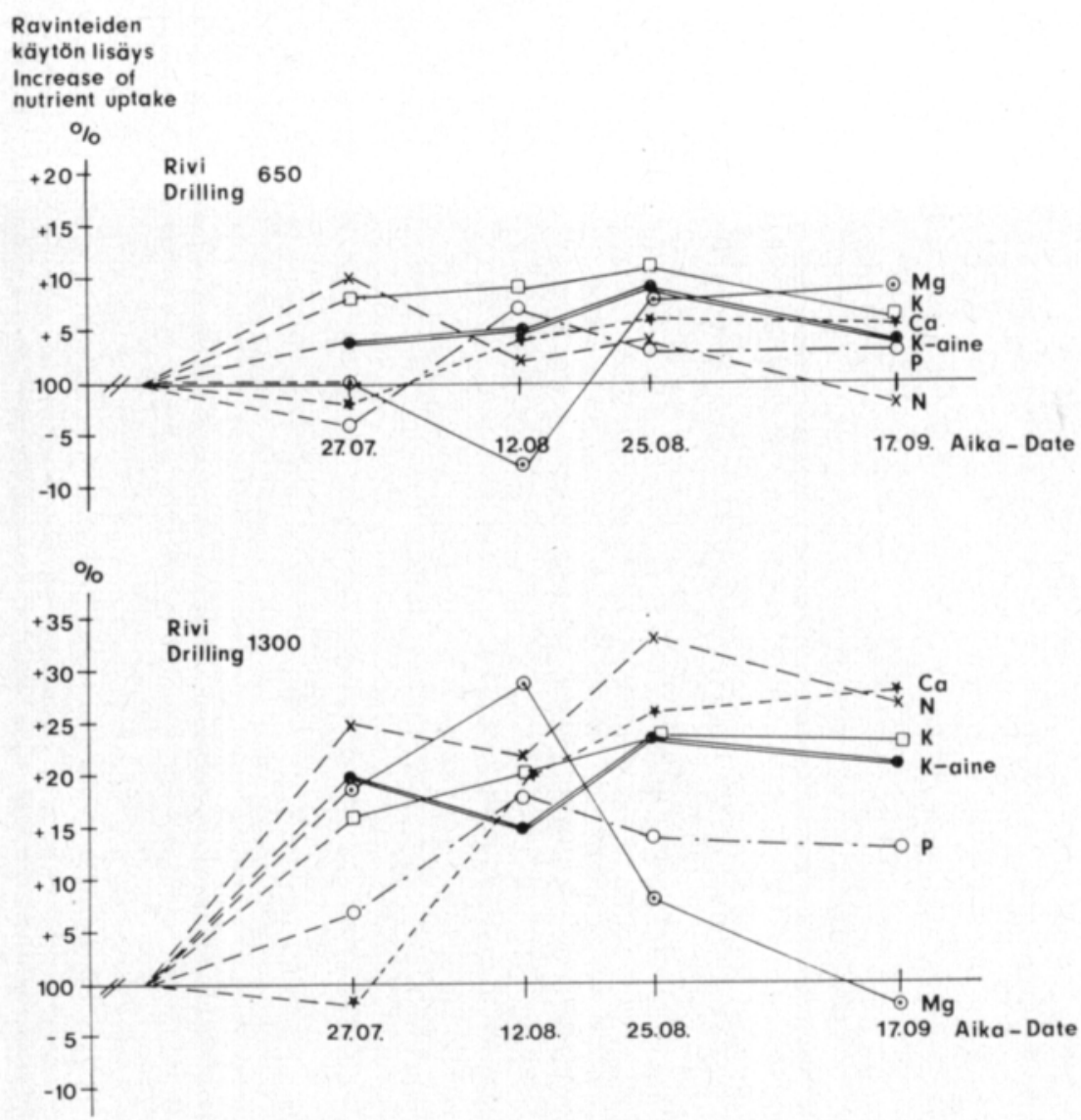

Piirros 8. Kuiva-ainesadon ja ravinnemäärien lisäys rivilannoitusta käytettäessä (Pinta-650 $=100$ ).

Figure 8. The increases of dry matter yield and nutrient uptakes using drilling (Broadcasting $650=100)$.

Koejäsen Rivi-650 (Piirros 8) käytti typpeä alkukesästä runsaasti, mutta keskikesästä lähtien suhteellisen niukasti. Fosforin käyttö oli niukanlaista suurimman osan kasvukautta, kaliumin tasaisen runsasta koko kasvukauden. Kalsiumin käyttö oli alussa suhteellisen niukkaa, mutta parani loppukesää kohti. Magnesiumin käyttö näytti sangen oikulliselta.

Koejäsen Rivi-1300 (Piirros 8) tuotti selvästi suurimman kuiva-ainesadon syksyllä. Tässä koejäsenessä typen käyttö oli suhteellisen runsasta koko kesän, fosforin käyttö puolestaan niukkaa suurimman osan kesästä. Kalin käyttö oli tasaista koko kasvukauden, kalsiumin alkukesästä sangen niukkaa. Magnesiumin käyttö väheni puolestaan syyskesällä romahdusmaisesti.

Sijoitus-650-lannoituksessa (Piirros 9) typen käyttö lisääntyi alkukesästä huomattavasti, mutta väheni myöhemmin voimakkaasti ilmeisesti niukan lannoituksen johdosta. Fosforin, kaliumin ja kalsiumin käyttö seurasi suhteellisen hyvin kuiva-ainesadon lisääntymistä. Magnesiumin käyttö oli tässäkin tapauksessa oikullista. 


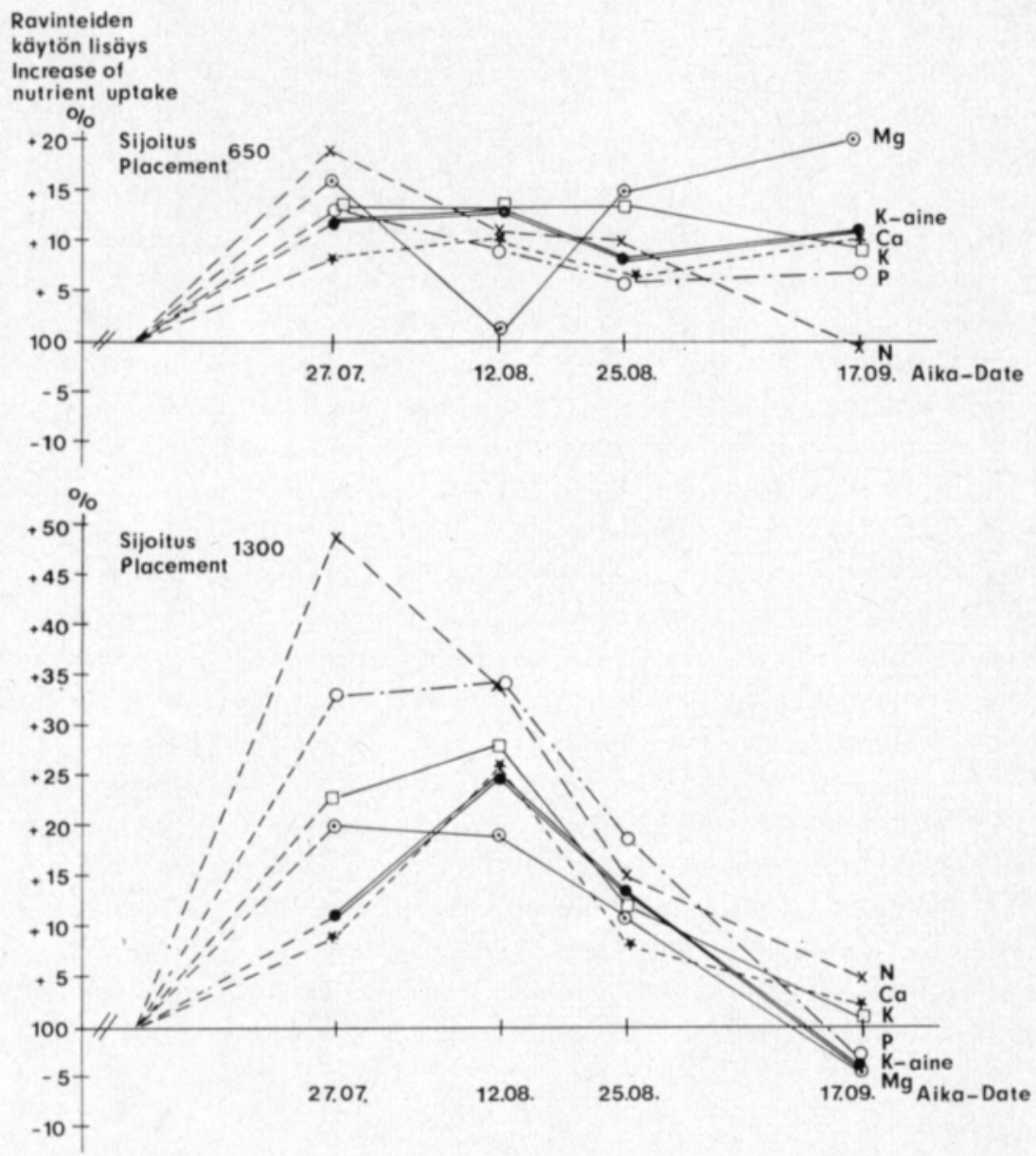

Piirros 9. Kuiva-ainesadon ja ravinnemäärien lisäys sijoituslannoitusta käytettäessä (Pinta-650 = 100).

Figure 9. The increases of dry matter yield and nutrient uptakes using placement (Broadcasting $650=100)$.

Koejäsen Sijoitus-1300 (Piirros 9) käyttäytyi muista poikkeavasti. Kuivaainesato nousi keskikesällä sangen suureksi, mutta sen kasvu pysähtyi syyskesällä kokonaan. Ravinteiden käyttö näytti kuitenkin olevan niin runsasta, että on vaikea olettaa minimitekijän olevan ravinteissa, ehkä magnesiumia lukuunottamatta. Syytä lienee haettava häiriintyneestä veden saannista.

Verrattaessa näitä piirroksia Taulukon 2 korrelaatiokertoimiin, näyttää siltä, että kunkin ravinteen sisällä korkea korrelaatiokerroin kytkeytyy ajoittaiseen tai jatkuvaan niukkuuteen, mikä voitaneen tulkita myös satoon vaikuttavaksi minimitekijäksi. Se, että eri ravinteiden välisissä korrelaatiokertoimissa oli selviä tasoeroja, on vaikeammin tulkittavissa samalta pohjalta. Esim. kaliumin korkeat korrelaatiokertoimet tuskin osoittavat kaliumin puutetta, vaan pikemminkin sen helppoa säätelytilannetta kuiva-aineen muodostumisen mukaan. Fosforin alhaiset korrelaatiokertoimet myöskään tuskin tarkoittavat sen vähäistä merkitystä kuiva-aineen muodostumisessa, joskin 
fosforin merkitys on suhteellisesti tärkeämpi mukuloiden kuin koko perunakasvin kuiva-ainesadon kehittymisessä.

\section{Tulosten tarkastelua}

Tämän tutkimuksen tulokset osoittivat, että sekä lannoitemäärän lisääminen pintalannoituksena että rivi- tai sijoituslannoituksen käyttäminen job. tivat selvästi parantuneeseen ravinteiden saantiin (vrt. AURA 1967, BAERUG ja Steenberg 1971, Varis 1973 b). Molempien keinojen yhdistäminen paransi vielä huomattavasti tulosta. Kuiva-ainesadon lisäys noudatti pääpiirteissään ravinteiden ottoa, vaikkakin tiettyä epäsuhdetta oli havaittavissa. Tämä ilmeni ajoittaisena kyseisen ravinteen pitoisuuden nousuna tai laskuna perunan lehdissä tai mukuloissa.

Typen käyttö alkukesästä lisääntyi kaikissa tapauksissa selvimmin. Kalin käyttö lisääntyi melko tarkasti kuiva-aineen määrän mukana. Sen sijaan fosforin, kalsiumin ja varsinkin magnesiumin käytössä oli huomattavaa vaihtelua kasvukauden aikana. Erityisesti kiinnittää huomiota koejäsen Sijoitus1300 , missä ravinteiden saanti alkukesästä oli sangen runsasta, mutta loppukesällä niiden saanti tyrehtyi kokonaan. Samalla kuiva-aineen muodostuminen häiriintyi. Syytä lienee haettava maan kosteusoloista (vrt. AURA 1967).

Lannoituksen lisääminen johti mukuloiden $\mathrm{N}$-pitoisuuden nousuun syksyllä. Mukuloiden P-pitoisuus nousi pinta- ja varsinkin sijoituslannoitusta käytettäessä. Mukuloiden K-pitoisuus nousi vain pintalannoituksessa. Ca- ja Mg-pitoisuudet muuttuivat myös hiukan lannoitustavasta riippuen. Muutokset olivat kaiken kaikkiaan suhteellisen lieviä (vrt. VARIS 1973 a).

\section{Tiivistelmä}

Rivi- ja sijoituslannoituksen vaikutusta perunan ravinteiden ottoon verrattuna pintalannoitukseen selvitettiin Hankkijan kasvinjalostuslaitoksen Anttilan koetilalla vuosina 1968-71. Kokeiden lannoituksena käytettiin 650 ja $1300 \mathrm{~kg} / \mathrm{ha}$ Yklv. Nostoaikoja oli 4, lajikkeena Rekord.

Typen ja kalin käyttö lisääntyi säännöllisimmin, kun taas fosforin ja erityisesti magnesiumin ja kalsiumin käytössä esiintyi epätasaista vaihtelua kasvukauden aikana.

Lannoituksen lisääminen muutti mukuloiden koostumusta syksyllä seuraavasti $(\%)$ : K-aine $21.8-21.8, \mathrm{~N} 1.14-1.27, \mathrm{P} 14.1-13.7, \mathrm{~K} 2.24-2.26$, Ca $0.038-0.040$ ja $\mathrm{Mg} 0.145-0.140$. Lannoitustavoittain pitoisuudet (\%) olivat seuraavat:

\begin{tabular}{|c|c|c|c|}
\hline & Pinta & Rivi & Sijoitus \\
\hline K-aine & 21.4 & 22.2 & 21.7 \\
\hline $\mathrm{N}$ & 1.30 & 1.33 & 1.32 \\
\hline P & 0.186 & 0.171 & 0.189 \\
\hline к & 2.30 & 2.21 & 2.24 \\
\hline $\mathrm{Ca}$ & 0.042 & 0.040 & 0.035 \\
\hline $\mathrm{Mg}$ & 0.144 & 0.142 & 0.142 \\
\hline
\end{tabular}




\section{KIRJALLISUUTTA}

AURA, E. 1967. Effect of the placement of fertilizer on the development of spring wheat. J. Scient. Agric. Soc. Finl. 39: 148-155.

Baerug, R. \& SteEnberg, K. 1971. Influence of placement method and water supply on the uptake of phosphorus by early potatoes. Potato Res. 14: 282-291.

LARPES, G. 1968. Rivilannoitus perunallekin. Koetoim. ja Käyt. 25: 46-48.

Nieminen, L., Kara, O. \& Elonen, P. 1967. Kokemuksia sijoituslannoituksesta. Maatal. ja Koetoim. 21: 42-49.

Pessi, Y., Ylänen, M., Leskelẽ, A. \& Syvälahti, J. 1970. Results of tests made with placement fertilization on the Kotkaniemi Experimental Farm. J. Scient. Agric. Soc. Finl. 42: 193-197.

VARIS, E. 1973 a. NPK-lannoituksen vaikutus perunoiden kemialliseen koostumukseen. J. Scient. Agric. Soc. Finl. 45: 468-482.

_- - 1973 b. NPK-lannoituksen vaikutus Pito-perunan ravinteiden ottoon. J. Scient. Agric. Soc. Finl. 45: 542-564.

- - \& LANNETTA. I. 1974. Lannoitustavan vaikutus perunasadon kehittymiseen ja sadon laatuun. J. Scient. Agric. Soc. Finl. 46: 328-340. 